Вивчення характеру розвитку тріщин, пов'язаного з розшаруванням на межі розділу ламінату композиту з волокнистих акрилових ламінатів (ВАЛ), проведено иляхом впливу на композит циклічних навантажень. Циклічне навантаження контролюеться зміщенням, що забезпечується машиною для випробування на опір втоми. Циклічне навантаження здійснювалося при різних значеннях коефічієнта зсуву, $R: 0,-1,-3$ та -5, при яких амплітуда зміщення також змінювалася до 0,15, 0,20, 0,30 м.м для кожного значення $R$. У даному дослідженні вивчення характеру розвитку тріщин зосереджено на негативному циклі $R$, тому композит піддається циклічним випробуванням при стискаючому навантаженні. Результати, отримані в даному дослідженні, показують, що в цих випадках при менших значеннях коефічієнта зміщення -3 та -5, втомний ресурс $i$ довжина трішин ВАЛ збільшуються, а при збільшенні амплітуди зміщення до 0,30 мм втомний ресурс $і$ довжина тріщин скорочуються. Швидкість розвитку розшарування вище при $R=0$, ніж при негативному значенні R. Крім того, бічне стиснення матеріалу назовні по області тріщини може сприяти розвитку розшарування при негативному відношенні циклів зсуву, бічне стиснення зростає при більш негативному відношенні зміщення. Більи того, розшарування може відбуватися перед вершиною тріщини, коли максимальне зміщення становить 0,20 мм або вище, $і$ це призводить до прискорення розвитку тріщин

Ключові слова: розвиток тріщин, розшарування, циклічні умови, волокнисті акрилові ламінати
UDC 621

DOI: $10.15587 / 1729-4061.2018 .139219$

\section{THE RELATION OF CRACK PROPAGATION BEHAVIOUR AND DELAMINATION ON FIBRE ACRYLIC LAMINATES UNDER VARIOUS CYCLIC CONDITIONS}

\author{
Anindito Purnowidodo \\ Doctor of Technical Sciences, \\ Associate Professor* \\ E-mail: Anindito@ub.ac.id \\ Khairul Anam \\ Lecturer* \\ E-mail: k_anari27@yahoo.com \\ Bagus Maulidika \\ Undergraduate Student* \\ E-mail: bagusgetoch@gmail.com \\ *Department of Mechanical Engineering \\ Brawijaya University Malang \\ Jalan. Mayjend Haryono, 167, Malang, \\ Indonesia, 65145
}

\section{Introduction}

Nowadays, composites are widely used in many aspects of human life, and they can be encountered easily in our daily activities [1]. The advantages of composites cannot be found in other materials because they have a combination of at least two types of materials, thus, the properties achieved are a combination from the materials composing a composite, and the properties are not displayed by any single material. A composite may combine properties required in engineering structures such as high strength, outstanding fatigue resistance and lightweight [1-3]. Those combination properties cause composites to become materials taking over gradually the role of metals as materials of engineering structures in the near future.

Like in other materials used as members of structures, flaws or defects such as cracks may be encountered in a composite. One of the most common types of composites used as a structural material is a laminate composite type. The fibre metal laminates (FMLs) composite is the type of composites used in a structure requiring combination properties such as lightweight, high fatigue resistance and strength as well as good ductility. Those properties can be obtained by combining a fibre-reinforced composite and a metal [2, 3].

\section{Literature review and problem statement}

It is very common that structures work under dynamic loads, and they are rare to be subjected to static loads. If there are defects such as cracks in a material of the structure loaded under dynamic loads, the cracks may propagate to its critical length, which endangers the safety of the structure. The crack propagation caused by the dynamic load may also occur on the composite materials such as FMLs [2]. The crack propagation taking place in the FMLs is associated with the delamination occurring over the crack region behind the crack tip $[4,5]$. Although the crack propagation behaviours on FMLs have been well known, and it has been known that the crack propagation is similar to the monolithic metal [2-6]. On the FMLs, the crack propagation is obg served on the metal laminate but over the wake of the crack, the fibre composite is still intact causing fibre bridging on the wake, thus, it reduces the effective stress advancing the 
crack and leads to a decrease in the crack propagation rate $[2,4-7]$. However, the mechanism how the crack propagates has not been well understood yet because the propagation involves the interaction between the fibre-epoxy composite laminate and the metal laminate in the region nearby the crack tip, and the propagation is affected by the interface condition between the laminates in which the delamination occurs $[4,5]$. In addition, the previous investigations of the crack propagation relating to the delamination on the FMLs were focused on the tensile cyclic loads [7-11] not involving the compressive cyclic load.

In the monolithic metal, the crack propagation behaviours depend on the residual stress state condition in front of the crack tip $[12,13]$. The residual stress is caused by the plastic deformation in the tiny element material in the zone in front of the crack tip, and this takes place because the zone is under high-stress concentration [14-17]. It is found that the residual stress may retard or accelerate the crack propagation if the crack is cycled under variable amplitude loads [12-16, 18-21]. The main cause of the retardation or acceleration of the crack depends on the residual stress state developing just in front of the crack tip or in front of the notch root. If the compressive residual stress develops, the retardation of the crack propagation occurs. However, if the tensile residual stress develops just in front of the crack tip, the crack propagation is accelerated, thus, it causes the fatigue life to be shorter [16, 22]. In the FMLs case, the crack propagation behaviour depends not only on the zone in front of the crack tip of the metal laminate but also the interface between the metal and the fibre-epoxy composite laminate. Some efforts have been carried out to investigate how the interface influences the crack propagation behaviour $[2,4,5]$. By using the etching or digital interference camera [2, 4, 5], it can be known that the delamination occurring in the interface is associated with the crack propagation behaviour, and the cause of the delamination is the shear stress developing between a metal layer and a fibre-epoxy composite layer. The direction of the shear stress is parallel to the load direction. The shear stress is caused by the bridging stress. The bridging stress develops over the crack region because loads of the crack region in the metal layer are transferred to the fibre-epoxy composite layer. The shear stress leads to shear deformation in the interface of the metal layer and the fibre-epoxy composite layer. Because the shear stress is in a cyclic condition, the delamination grows gradually behind the crack tip, and it develops as the crack propagates [4,5]. If the delamination becomes larger, the bridging stress decreases, and as a result the crack propagation rate increases. On the other hand, if the delamination is smaller, the bridging stress is higher along the crack region. The bridging stress affects the stress intensity factor of the crack tip of the metal layer. The high bridging stress lowers the stress intensity factor, thus, the crack propagation rate of the metal layer decreases, and its fatigue life is longer in comparison to the monolithic metal $[4,5]$.

Because the crack propagation relating to the cyclic load may occur in two possibilities, those are, retardation or acceleration, and because the previous investigations of the crack propagation behavior in the FMLs are focused on the positive (tensile) amplitude loads [2, 4, 5-7], thus, it is important to understand the crack propagation behavior of the FMLs when an assessment of a structure is conducted in any condition of the cyclic loads such as negative (ten- sile-compressive) amplitude loads. Therefore, in the present study, the investigation is focused on the relation of the crack propagation and the delamination under negative amplitude loads.

\section{The aim and objectives of the study}

The aim of the work is to understand the crack propagation behaviour associating with the delamination, especially conducted under negative constant amplitude loads because under compressive load is possible that there is a lateral movement to outward, which may contribute to the delamination.

To achieve this aim, the following objectives were set:

1. Instead of metal, because of transparency, the acrylic is used in order to be able to observe the development of the delamination in the interface of laminates while being cycled under fatigue loads with various displacement ratios.

2. The observation of the crack propagation behavior at the acrylic layer and the development of the delamination at the interface between the epoxy-fibre composite and the acrylic layers.

3. Detecting a lateral movement to outward in the region nearby the crack, especially when the value of displacement ratio is negative.

\section{Method of Study}

In the present study, the fibre acrylic laminates (FALs) composites were made using the vacuum assisted resin transfer moulding (VARTM) technique as shown in Fig. 1, and it was carried out in laboratory room temperature conditions. The commercial acrylic with the thickness of $1.5 \mathrm{~mm}$ was selected to compose the composite, and the tensile strength and the elongation, respectively, were $50 \mathrm{MPa}$ - and $3.5 \%$. The resin-epoxy was used as an adhesive to make the epoxy-fibre composite laminate, and the curing time of the epoxy as recommended by the manufacturer was 12 hours. The woven fibre-glass was selected to reinforce the FALs, and the fibre orientation was arranged in this manner to be directed to $0^{0} / 90^{0}$ to the load direction. The fibre is shown in Fig. 2. The double-edge crack type of the specimen was selected in the present study, thus the sharp notch with $3.0 \mathrm{~mm}$ in length and $0.2 \mathrm{~mm}$ in width of the notch root was cut on every edge of the specimen. Fig. 3 shows schematically the dimension of the specimen and the laminate sequence of the FALs. The length of $50 \mathrm{~mm}$ from both ends of the specimen was used when it was griped to the testing machine. With reference to Fig. 1, to make the specimens, the mixture of epoxy-hardener with the ratio of 2:1 was poured into the container, and then the vacuum pump sucked the epoxy from the container. Before that, the laminates with the sequence as indicated in Fig. 3 were put into the mould in that mant ner, and it was wrapped by the plastic bag film, which was sealed in order to prevent air to be sucked into the mould and to keep the vacuum condition. After the epoxy filled up completely the mould, the vacuum pump was turned off, and it was left for 12 hours for curing. Using this technique, the $3.95 \mathrm{~mm}$ of the specimen thickness was obtained. The tensile strength and the elongation of the FALs obtained, respectively, were $105 \mathrm{MPa}$ - and $3.6 \%$. 


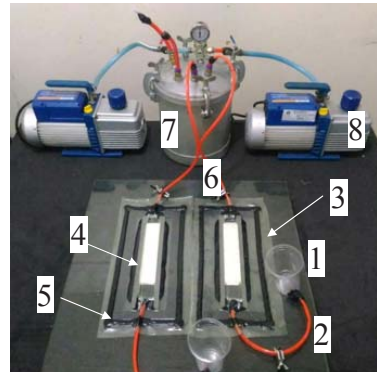

1. Epoxy container

2. Inlet tube

3. Bag film

4. Specimen mold

5. Sealant tape

6. Outlet tube

7. Resin trap

8. Vacuum pump

Fig. 1. Vacuum Assisted Resin Transfer Molding (VARTM)

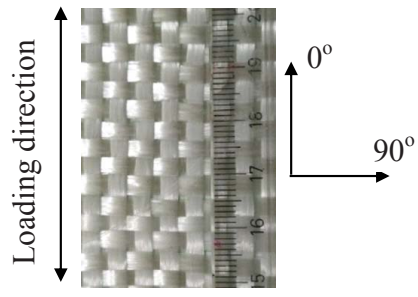

Fig. 2. Woven fiberglass
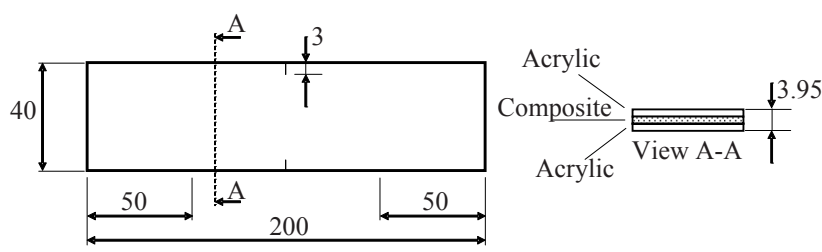

$\stackrel{\text { Loading direction }}{\longrightarrow}$

Fig. 3. Dimension of the FALs composite specimen ( $\mathrm{mm}$ ) and the laminate sequence

Because the acrylic is much more brittle than metals, as the crack emerged from the notch root in a short length, the crack advanced rapidly when the FALs was subjected to constant cyclic loads controlled by force. It was very difficult to observe the crack propagation. Because of this reason, in the present study, every specimen was subjected to cyclic loads controlled by the constant displacements with the frequency of $7 \mathrm{~Hz}$, and the test was carried out in the laboratory-room temperature condition with the servo-hydraulic fatigue machine. Table 1 shows the testing conditions. The displacement ratio, $R$, is defined as the comparison of the minimum displacement, $D_{\min }$. and the maximum displacement, $D_{\max }$. of the constant cyclic displacements, and $D_{\text {amp. }}$. is the displacement amplitude. An example of the cyclic displacement pattern is depicted in Fig.4 when the displacement ratio, $R$, is zero. The average length of the crack propagating from both sides of the specimen is denoted as the semi-crack length, $a$, which was measured including the notch length. The delamination length, $L$, is defined as the average length of delamination measured perpendicular to the crack direction from the crack line to the farthest point in which the delamination occurred. To observe the crack propagation and the delamination development, the travelling digital microscope with the accuracy of $10 \mu \mathrm{m}$ connected to a personal computer was used. To indicate that, there was a lateral movement to outward in the region nearby the crack because of the negative displacement, metal pins were inserted into the blind holes on both surfaces of the specimen with the diameter of $0.5 \mathrm{~mm}$ and $0.5 \mathrm{~mm}$ in depth. The holes were drilled on the position of $1 \mathrm{~mm}$ in front of the notch root and above the notch root. The pins were connected to the extensometer with the accuracy of $1 \mu \mathrm{m}$. Fig. 5 shows the configuration of the extensometers and the pins.

Table 1

Testing Conditions

\begin{tabular}{|c|c|c|c|c|}
\hline No & $R$ & $D_{a}(\mathrm{~mm})$ & $D_{\text {max. }}(\mathrm{mm})$ & $D_{\min .}(\mathrm{mm})$ \\
\hline 1 & \multirow{3}{*}{0} & 0.15 & 0.30 & 0 \\
\hline 2 & & 0.20 & 0.40 & 0 \\
\hline 3 & & 0.30 & 0.60 & 0 \\
\hline 4 & \multirow{3}{*}{-1} & 0.15 & 0.15 & -0.15 \\
\hline 5 & & 0.20 & 0.20 & -0.20 \\
\hline 6 & & 0.30 & 0.30 & -0.30 \\
\hline 7 & \multirow{3}{*}{-3} & 0.15 & 0.075 & -0.225 \\
\hline 8 & & 0.20 & 0.10 & -0.30 \\
\hline 9 & & 0.30 & 0.15 & -0.45 \\
\hline 10 & \multirow{3}{*}{-5} & 0.15 & 0.05 & -0.25 \\
\hline 11 & & 0.20 & 0.07 & -0.33 \\
\hline 12 & & 0.30 & 0.10 & -0.50 \\
\hline
\end{tabular}

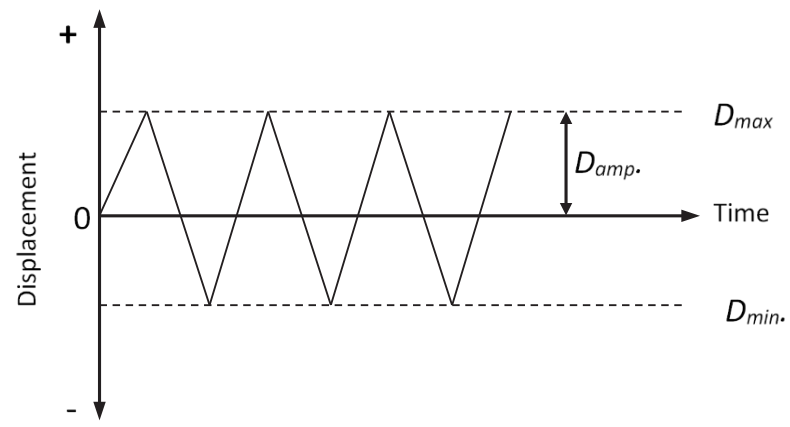

Fig. 4. An example of a representative cyclic pattern

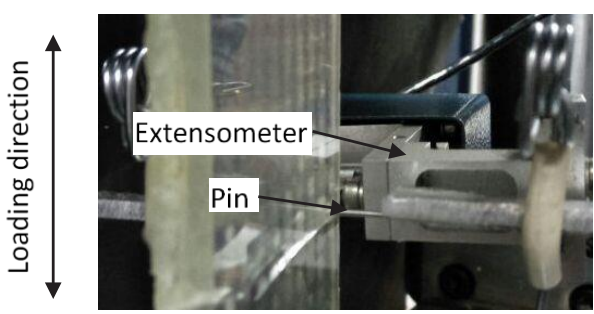

Fig. 5. The position of the extensometer attached to a specimen

\section{The Crack Propagation Behaviours}

Fig. 6 shows examples of the crack propagation and the development of the delamination when the displacement ratio, $R$, is 0 and the displacement amplitude, $D_{a}$ is 0.2 . The white arrows point the crack tip, and the length, $L$, of the delamination is defined as shown in the figure. The figure shows that as increasing the number of cycles, the crack and the delamination length increase also. To con- 
firm that the white area in the figure is the area in which the delamination occurs, thus, the specimen was cut along the yellow dashed line as depicted in Fig. 6, $c$, and after being polished the view of A-A can be seen in Fig. 6, $d$, in which there is a gab pointed by the red arrow between the fibre-epoxy composite laminate and the acrylic laminate. The gab indicates that the delamination took place. From these examples, it is found that the delamination may occur in front of the crack tip, and it is unlike to the previous investigation reporting that delamination begins to develop behind the crack tip [2-5]. However, what is found in the present investigation cannot be compared to the previous one because instead of aluminium laminate, the present study used the acrylic laminate to represent a more brittle material. The delamination phenomenon found in this study relates to the crack propagation behaviours affected by the cyclic conditions.

The effect of the cyclic conditions on the crack propagation is shown in Fig. 7. The figure shows that the displacement amplitude, $D_{a}$, affects the fatigue crack propagation behaviour on every displacement ratio, $R$, and as the displacement amplitude increases, the fatigue life becomes to be shorter. Even, in the case of $R=0$ and $D_{a}=0.3$ as shown in Fig. 7, $a$, after being cycled in a few cycles, the crack advanced in the short distance in front of the notch root. Afterwards, because of the highly maximum displacement, $D_{\max }$, the crack advanced in a monotonic fashion until complete fracture. This is typical of a brittle material such as acrylic, in which the crack is easier to advance although the crack is shorter in comparison to a ductile material such as aluminium [1, 17]. In addition, the increasing value of $D_{a}$ causes the crack propagation rate to be higher, and the crack propagation rate tends to decrease in all cases of $R$ as the crack increases. Except in the case of $R=-5$, which is slightly increasing. When the displacement ratio is -1 as indicated in Fig. $7, b$, the crack propagation behaviour is similar to that occurring in the case of $R=0$. In exception when the $D_{a}$ is 0.3 , in this case, the fatigue life is longer than that in the previous displacement ratio. Although the value of $D_{a}$ is equal, the $D_{\max }$. is lower than that of $R=0$. Because of this, the critical stress intensity factor may be reached in the longer crack. Hence, the fatigue life becomes longer. In the case of $R=-3$, when the displacement amplitude is as low as 0.15 , Fig. 7 , c shows that after emerging from the notch root in a short distance, the crack does not propagate. The arrow in the figure points that the test was stopped after reaching more than 1 million cycles. Because of this, the crack propagation rate of this condition is not be plotted. Even, the crack did not emerge from the notch root if the cyclic conditions with the value of $R$ and $D_{a}$, respectively, are -5 and 0.15 as plotted in Fig. $7, \mathrm{~d}$, and the test was stopped also when the number of cycles had reached more than 1 million as indicated by the arrow.

To summarize the effect of the fatigue cyclic conditions on the crack propagation behaviours, the relation of the displacement amplitude, $D_{a}$, to the number of cycles, $N$, for every condition of the displacement ratio, $R$, is plotted as shown in Fig. 8. From this figure, it can be known that the fatigue life stated in the number of cycles required to completely fracture is lowered by the increasing of the displacement amplitude, and the fatigue life is higher when the value of $R$ is lower for every displacement amplitude. These behaviours associate with the delamination that took place in the interface between the fibre-epoxy composite laminate and the acrylic laminates, and this will be discussed in detail in the next section.

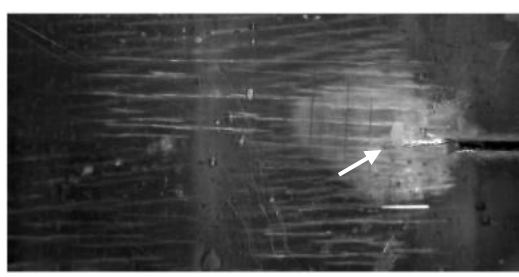

$2 \mathrm{~mm}$

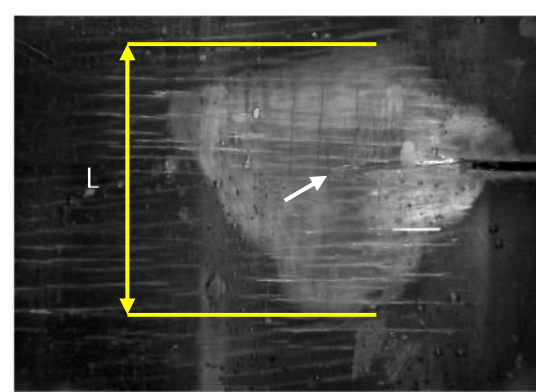

$b$

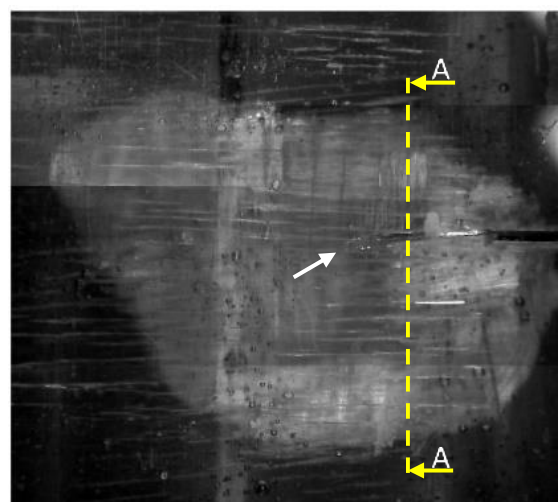

c

Fiber-epoxy composite laminate

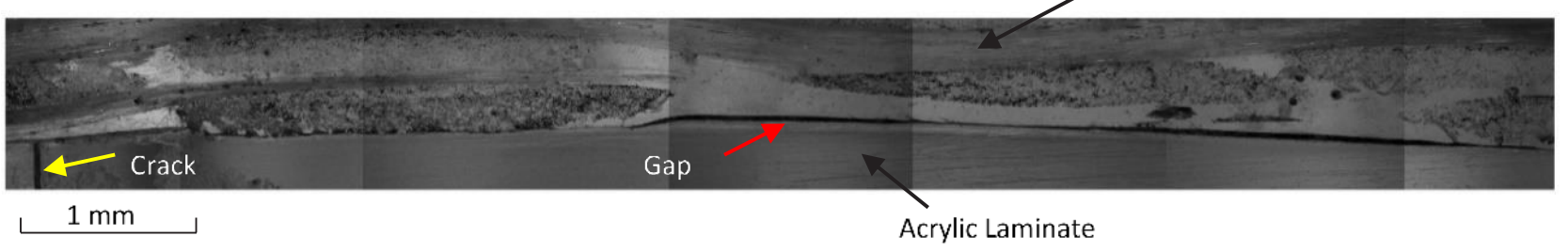

$d$

Fig. 6. Examples of the development of the crack propagation and the delamination: $a-5,000$ cycles; $b-30,000$ cycles; $c-40,000$ cycles; $d-$ view of $A-A$ for $R=0$ and $D_{a}=0.2 \mathrm{~mm}$ 

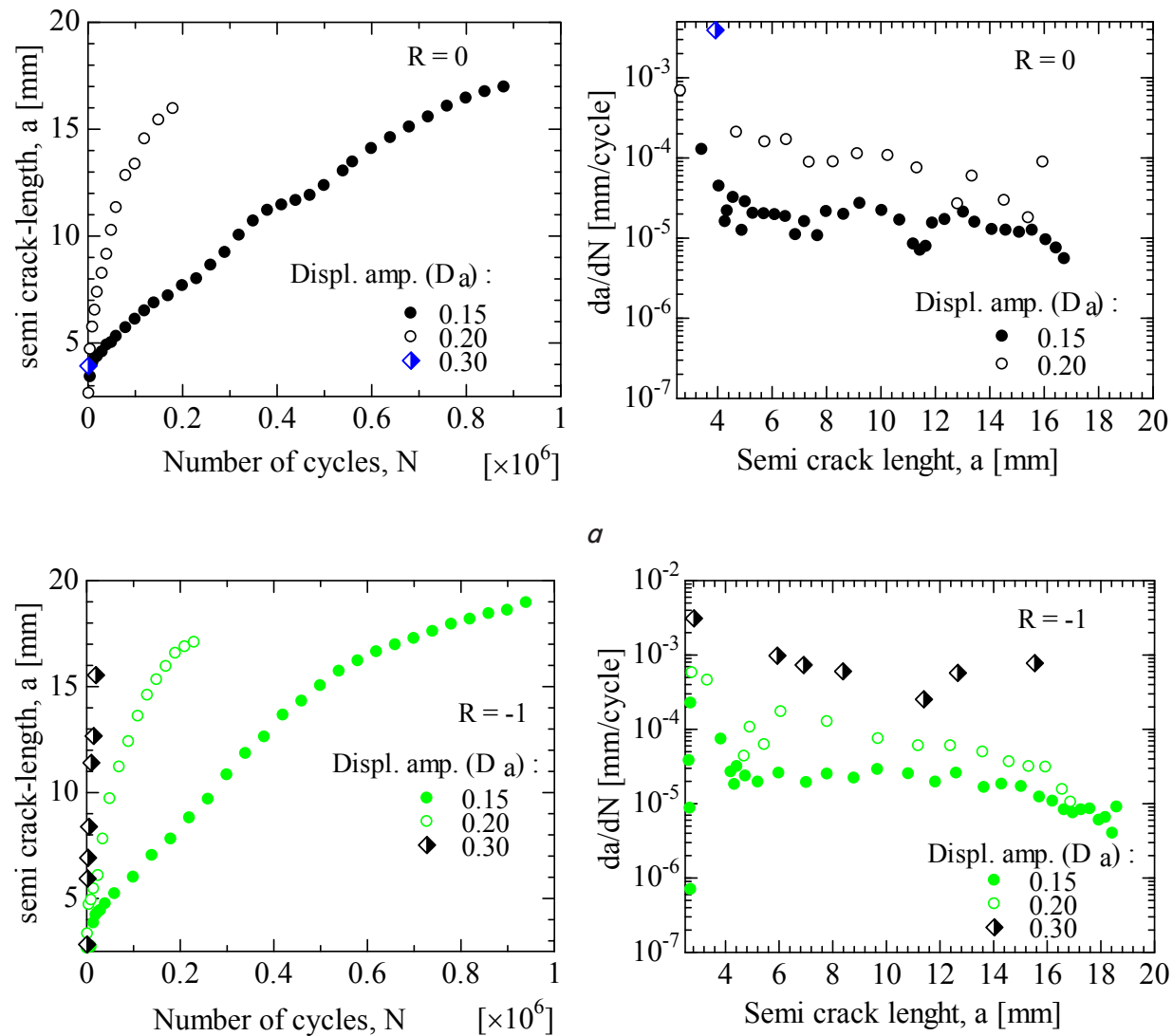

$b$
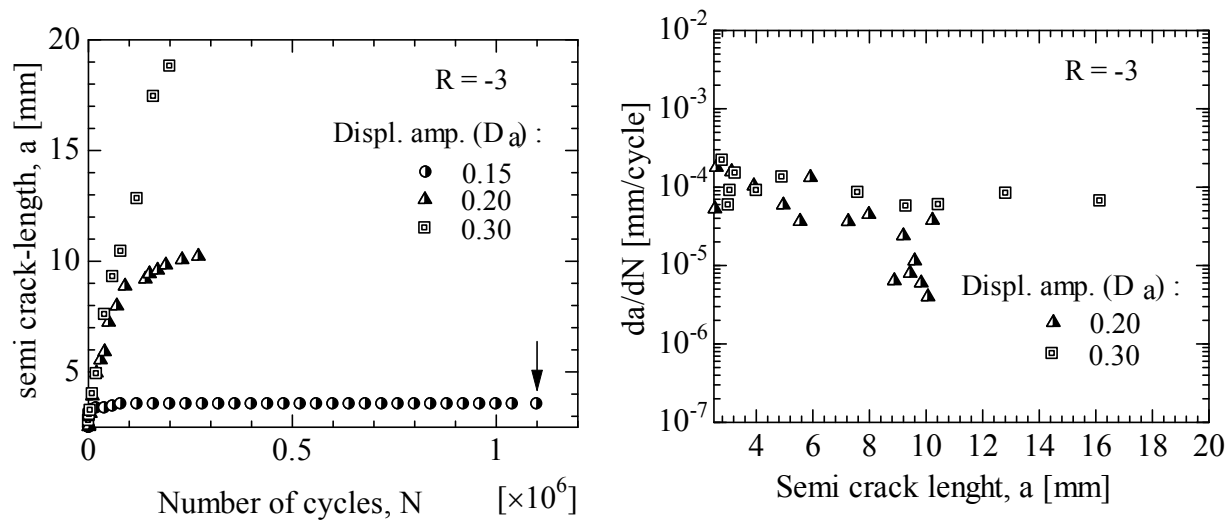

c
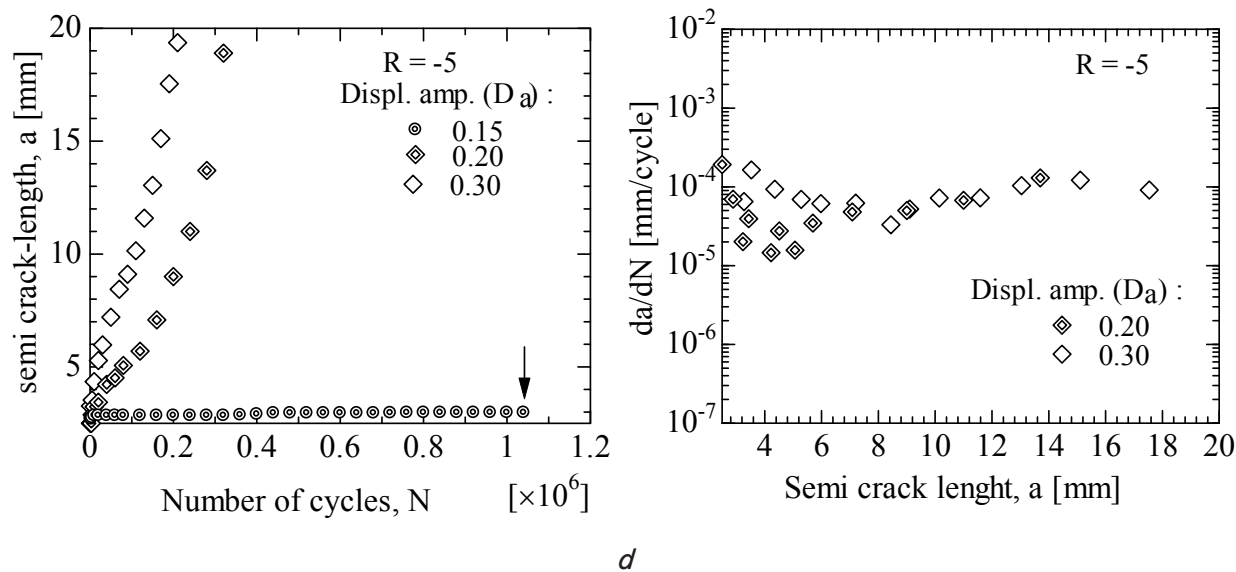

Fig. 7. The effect of the displacement amplitude, $D_{a}$, and the displacement ratio, $R$, on the crack propagation behaviors: $a-R=0 ; b-R=-1 ; c-R=-3 ; d-R=-5$ 


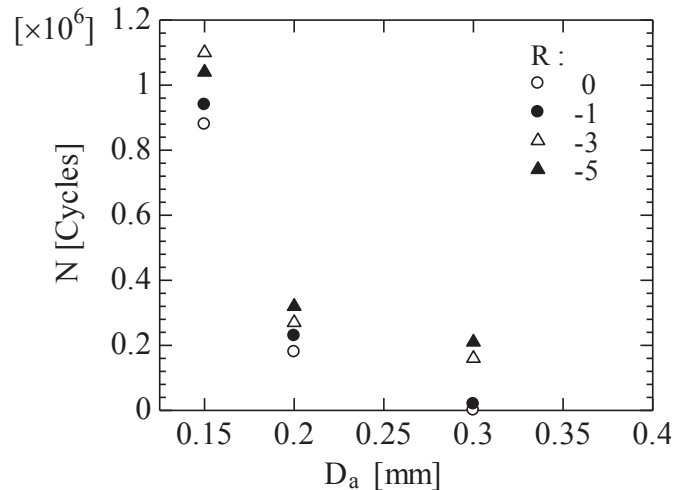

Fig. 8. The relation of the amplitude displacement, $D_{a}$ to the number of cycles, $N$

\section{Discussion of the Delamination Effect on Crack Propagation}

Because the crack propagation behaviour in a composite laminate type relates to the delamination occurring at the interface between laminates [2-4]. Hence, using the FALs composite in the present study, the delamination occurred at the interface between the fibre-epoxy and the acrylic laminate could be observed directly when the specimen was subjected to certain cyclic displacement. Fig. 9 shows an example of the development of the delamination in connection with the crack propagation subjected to the cyclic condition with $D_{a}=0.15$ and $R=0$. The blue arrows and the white one, respectively, point the crack tip and the area of delamination. The figure shows that delamination does not always begin to develop just behind the crack tip as reported by previous investigations [2-5] but it can develop in front of the crack tip. It has been known that the development of the delamination is caused by the shear stress in the interface between the laminate, and the shear stress is caused by the bridging stress over the crack region [2-4]. As the delamination area to be larger over the crack region, the bridging stress is lower, consequently the crack propagation rate increases [2]. Hence, according to the figure, the presence of delamination in front of the crack tip indicates that shear stress may take place in the region in which the bridging stress does not occur. In other words, in the delamination area, there is no shear stress. Therefore, it is plausible that delamination taking place in front of the crack tip also contributes to increasing the crack propagation rate. With respect to Fig.9, up to 230,000 cycles, the crack propagates inside the delamination region. This means that in front of the crack tip, the delamination is present. This is the reason why the crack propagation rate tends to be higher than in the following cycles. In the following cycles when the number of cycles is greater than 230,000 , the delamination is left behind the crack tip, thus, it causes the bridging stress to be increased leading to the crack propagation rate to become lower as well as the fatigue life becomes longer in comparison to other cyclic conditions. The phenomenon found as shown in Fig. 9 is similar to every value of the displacement ratio, $R$, if the maximum displacement, $D_{\max }$, is not greater than 0.30 . The crack propagation nearby the notch root is always within the delamination area. It is possible that the notch effect causes delamination to be easy to develop because the region in front of the notch root is a zone in which the stress is highly concentrated, and because the acrylic is more brittle than a metal. As a result, the crack is easy to advance in front of the notch root. Next, together with bridging stress developing behind this crack tip in the high-stress concentration region, the high shear stress in the laminates interface develops also, so the delamination develops easily. The development of the delamination is summarized in the following figure.

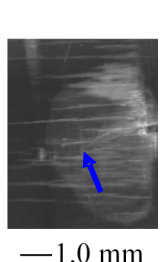

10,000

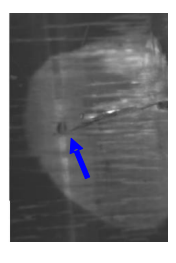

60,000

b

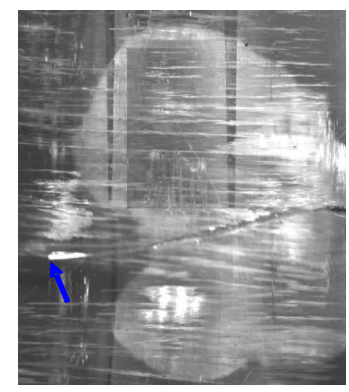

$-1.0 \mathrm{~mm}$
350,000

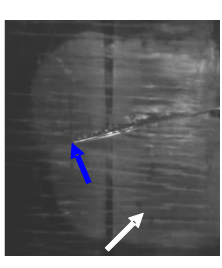

140,000

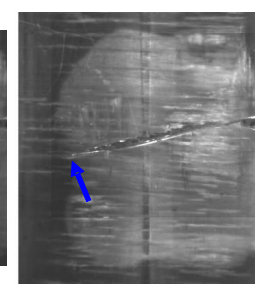

230,000 cycles

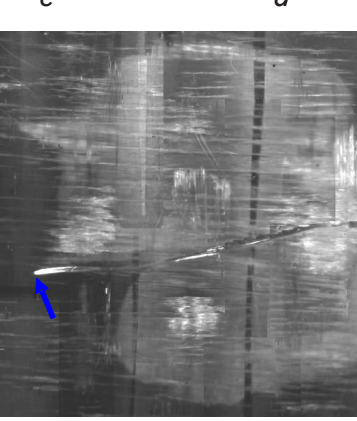

500,000 cycles

Fig. 9. The delamination development and crack propagation under $D_{a}=0.15$ and $R=0: a-10,000$ cycles;

$b-60,000$ cycles; $c-140,000$ cycles; $d-230,000$ cycles; $e-350,000$ cycles; $f-500,000$ cycles

As the number of cycles increases, the crack continues to propagate, and the delamination length, $L$, also increases as observed in the present study. Because the delamination size represented by the delamination length becomes to be larger, the bridging stress is smaller, and it induces the cyclic shear stress in the interface of the laminate to be smaller also [2-4]. This leads to a decrease in the delamination growth rate, $d L / d N$. The decreasing of the delamination growth rate was also observed in the present study as shown in Fig. 10. Because of this, the bridging stress does not continue to become to be lower, and this causes the crack propagation rate to tend to decrease as the crack to be longer. As mentioned in the previous section, in the case of the cyclic condition was $R=0$ and $D_{a}=0.3$, the crack propagated in a monotonic fashion after being cycled under a few numbers of cycles and reaching a short crack length. In this case, the delamination length and the delamination growth rate were measured before the crack had advanced monotonically. In the same manner of the measurement, this was carried out on other specimens. The result of the measurement is shown in Fig. 10, $a$. Besides decreasing the delamination growth rate, this figure shows that in the lower value of the $D_{a}$ the delamination growth rate decreases, and this also takes place with other values of $R$ as shown in Fig. 10, $b-d$, respectively. The delamination grew slowly as shown in Fig.10, $c$ in which $\mathrm{R}$ is -3 , and $D_{a}$ is 0.15 . Even, with the same magnitude of $D_{a}$ in the case of the value of $R$ is -5 , the delamination did not grow as shown in Fig. 10, $d$. Because of these, high bridging stress is maintained, and as a result, the crack does not propagate as shown in Fig. 7. 

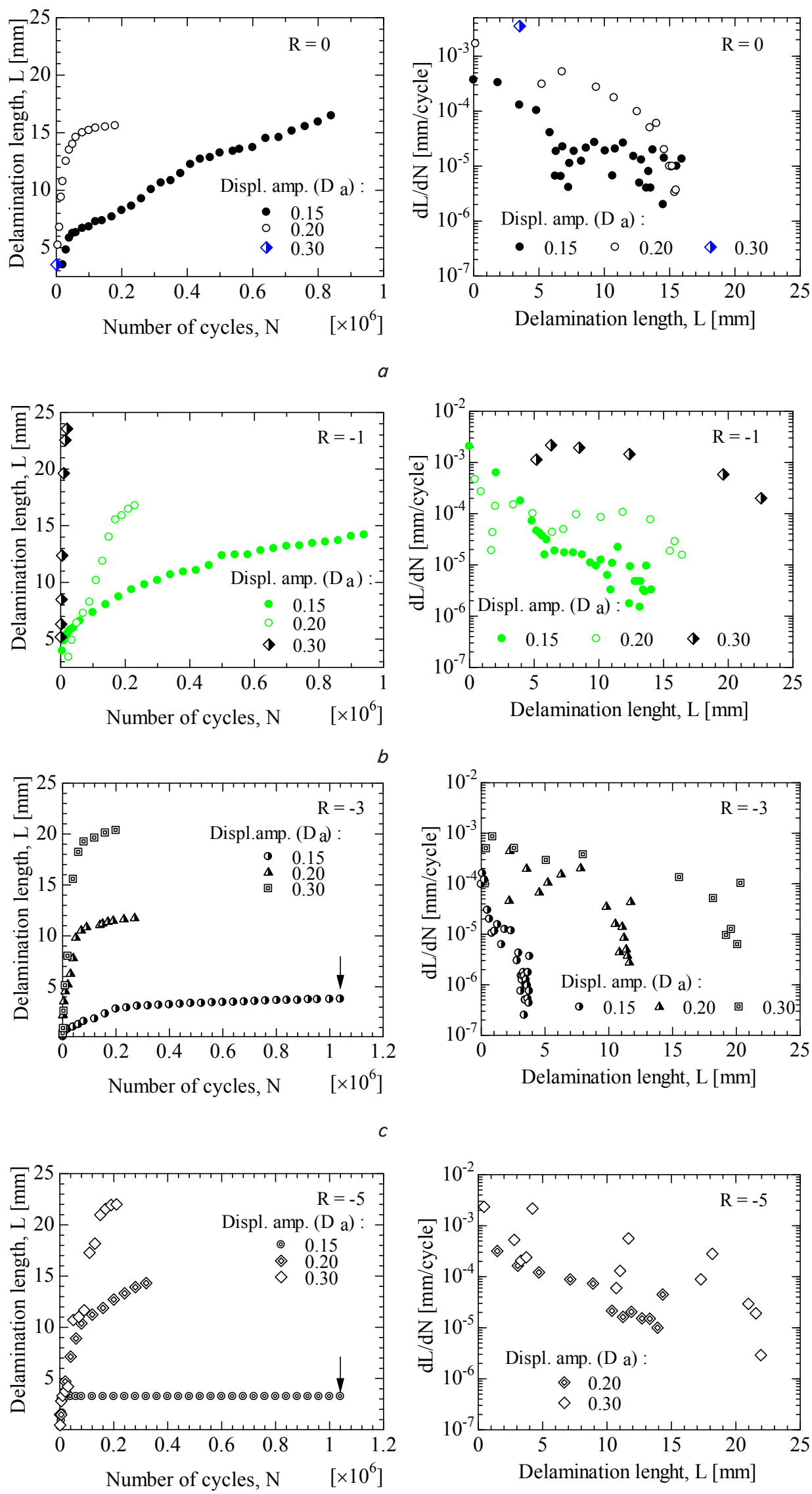

Fig. 10. The effect of the displacement amplitude, $D_{a}$, and the displacement ratio, $R$, on the development of delamination: $a-R=0 ; b-R=-1 ; c-R=-3 ; d-R=-5$ 
Fig. 11 shows the example plot of the comparison of the delamination development for every displacement ratio, $R$, with $D_{a}=0.3$. It is difficult to present all the comparisons for every displacement amplitude, $D_{a}$, because of the limited space here, and because the tendency is almost the same, thus, only as shown in Fig. 11 is presented. Fig. 11 shows that the higher value of $R$ tends to increase the delamination growth rate. Therefore, the crack propagation rate is higher when the value of $R$ is higher also although it is cycled under the same magnitude of the constant displacement amplitude.

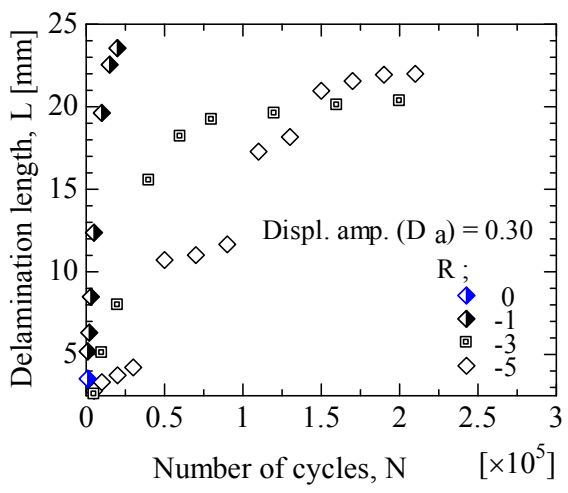

$a$

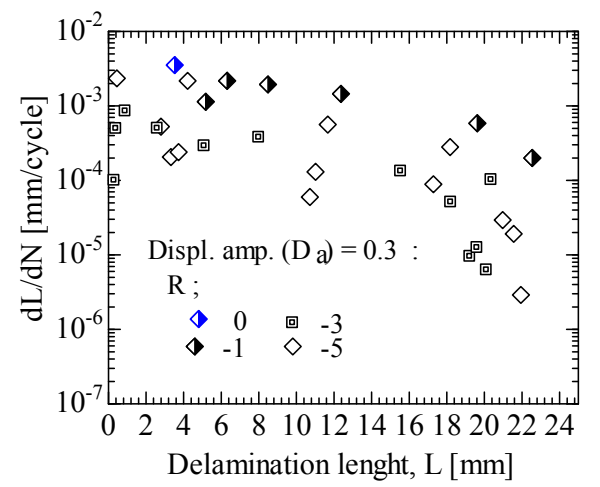

b

Fig. 11. The comparison of the delamination development when the displacement amplitude is $0.3 \mathrm{~mm}$ with various displacement ratios: $a-N$ vs. $L ; b-L$ vs. $d L / d N$

It is well known that the development of the delamination is associated with the crack propagation behaviours. However, most of the studies reported the crack propagation after being cycled under zero or positive stress ratio cases, and they reported that the size of the delamination is equal to the crack length [2-6]. For those reasons, the present study investigated the effect of the cyclic condition under tensile-compressive constant amplitude load conditions. However, as mentioned before because the acrylic is brittle, thus, the cyclic is controlled by the displacement instead of stress. Fig. 12 shows the effect of the displacement amplitude, $D_{a}$, on the crack length, $a$, and delamination length, $L$, respectively. The plot only indicates the crack length, and the plot with the dashed line is the delamination length. These plots are based on when the specimens were considered completely fracture, or they were stopped when the crack did not continue to propagate after reaching at least 106 cycles. When $R=0$, the effect of the displacement amplitude on the crack length and the delamination length is the same. That is, the crack length together with the delamination length decrease as the displacement amplitude increases. In other words, the crack length and the delamination length are equal. However, when the value of $R$ is negative, the effect of the displacement amplitude varies. In the case of $R=-1$, the crack length and the delamination length do not coincide as in the previous case of $R$. In this case, the increasing of the displacement amplitude reduces the crack length, it is in contrast to the delamination length. The crack length is shorter when the displacement amplitude is higher because the maximum displacement, $D_{\max }$, is higher also at a higher amplitude. Hence, it causes the stress intensity factor in the crack tip to be higher. Because of this, the critical crack length is shorter, and then the crack will advance in the monotonic fashion. The shorter crack length is contributed also by the delamination size, which is longer with the higher value of $D_{a}$. The larger size of delamination is observed in the present study, although it was cycled under higher displacement amplitude with negative displacement ratio. This has an association with the lateral displacement in the region over the crack outward perpendicular to the load. This will be explained in the next paragraph. In the cases of $R$ are -3.0 and -5.0 , the increasing of the crack length caused by the displacement amplitude is equal to the delamination length, and when the displacement amplitude is as low as 0.15 as pointed by the arrow in the figure, the crack length and the delamination length are arrested. With these values of $R$, the crack length can reach longer crack than those of 0 and -1.0 because the maximum displacement is not high enough to advance the crack in a monotonic fashion in shorter crack length as in the 0 and -1.0 cases

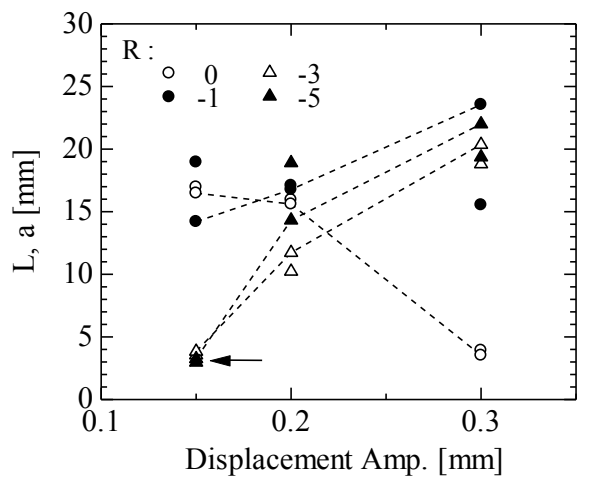

Fig. 12. The comparison between $L$ and $a$ on various $R$ and displacement amplitude

The indication that there is lateral contraction, which was detected by measuring the lateral movement outward and perpendicular to the specimen surface over the crack region is plotted in Fig. 13. Unfortunately, the measurement was not carried out in all conditions of the test. However, the result plotted in Fig. 13 may be enough to indicate that the lateral contraction, $X$, tends to be higher when the value of $R$ is smaller. This is the reason why the delamination could be observed, although it was subjected to the negative displacement ratio. 


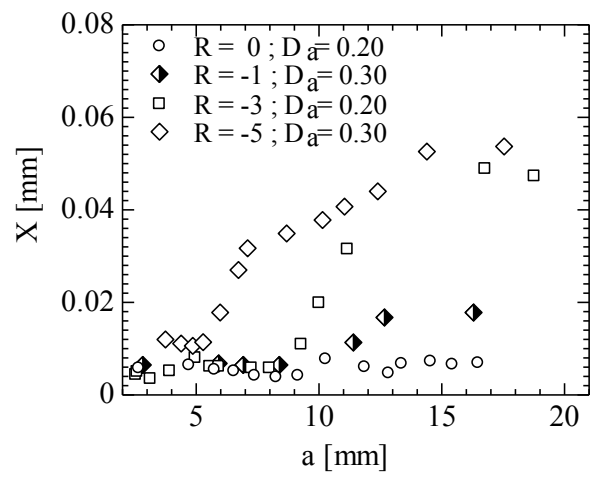

Fig. 13. The effect of displacement ratio, $R$, and displacement amplitude, $D_{a}$ on lateral contraction, $X$

Based on the phenomenon obtained in this study, the delamination may occur not only over the wake behind the crack tip but also it may occur in front of the crack tip depending on the cyclic load conditions, and the delamination responsible for the crack propagation behaviour of the FALs. In addition, it is also found that the negative amplitude loads may lead to the delamination to develop in which the development associates with the lateral contraction to outward. However, because it is well known that the crack propagation behaviour depends on the stress concentration in front of the crack tip and the stress intensity factor, hence, the stress analysis relating to the crack propagation behaviours of FALs is important to be conducted, especially, when the constant amplitude loads are negative. Therefore, how the delamination developing under negative amplitude loads affects the crack prop- agation behaviours can be more understood. The stress analysis will be conducted in the near future.

\section{Conclusions}

1. The delamination observed at the interface between the acrylic laminate and the laminate of fibre-epoxy composite associates with the crack propagation on the acrylic laminate of FALs composite.

2. The lower value of the displacement ratio, the fatigue life and the crack length of the FALs increased. However, the increasing of the displacement amplitude causes both the fatigue life and the crack length to be shorter. In the case of $R=0$, the crack length is easier to advance in comparison to other lower values of $R$ because in this case the maximum displacement, $D_{\max }$, is higher leading to the shear stress developing in the interface between the laminates over the crack region is higher also as indicated by the delamination growth rate being higher in the $R=0$ case. In addition, all cases of $R$ and $D_{a}$ show that the crack length and the delamination size are equal, except when the $R$ is -1.0 in which the crack length decreases as the displacement amplitude increases. This is in contrast to the delamination length. It is because the maximum displacement is high enough to advance the crack in a monotonic fashion in the shorter crack than those of -3.0 and -5.0 cases. In addition, the delamination observed taking place in front of the crack tip when the maximum displacement is high as in $R=0$ causing the crack propagation to increase.

3. The lateral contraction over the crack region to outward contributes to the development of the delamination when the ratio of the displacement cycles is negative, and the lateral contraction in higher when the displacement ratio is more negative.

\section{References}

1. Callister Jr. W. D., Retwisch D. G. Introduction in Fundamentals of Materials Science and Engineering, An Integrated Approach. Ch. 1. 3th ed. New Jersey: John Wiley \& Sons, Inc., 2008. P. 5-10.

2. Alderliesten R., Crack F. Propagation and Delamination Growth in Glare. 1th ed. Delft, Netherland: DUP Science, 2005. P. $1-4$.

3. Jones R. M. Introduction to Composite Materials-Mechanics of Composites Materials. 2th ed. Philadelphia, Taylor \& Francis, 1999. P. 11-15.

4. Khan S. U., Alderliesten R. C., Benedictus R. Delamination in Fiber Metal Laminates (GLARE) during fatigue crack growth under variable amplitude loading // International Journal of Fatigue. 2011. Vol. 33, Issue 9. P. 1292-1303. doi: https:// doi.org/10.1016/j.ijfatigue.2011.04.002

5. Delamination and fatigue crack growth behavior in Fiber Metal Laminates (Glare) under single overloads / Huang Y., Liu J., Huang X., Zhang J., Yue G. // International Journal of Fatigue. 2015. Vol. 78. P. 53-60. doi: https://doi.org/10.1016/j.ijfatigue. 2015.04.002

6. Dadej K., Bieniaś J., Surowska B. Residual fatigue life of carbon fibre aluminium laminates // International Journal of Fatigue. 2017. Vol. 100. P. 94-104. doi: https://doi.org/10.1016/j.ijfatigue.2017.03.026

7. Jones R., Kinloch A. J., Hu W. Cyclic-fatigue crack growth in composite and adhesively-bonded structures: The FAA slow crack growth approach to certification and the problem of similitude // International Journal of Fatigue. 2016. Vol. 88. P. 10-18. doi: https://doi.org/10.1016/j.jfatigue.2016.03.008

8. Nojavan S., Schesser D., Yang Q. D. A two-dimensional in situ fatigue cohesive zone model for crack propagation in composites under cyclic loading // International Journal of Fatigue. 2016. Vol. 82. P. 449-461. doi: https://doi.org/10.1016/ j.ijfatigue.2015.08.029

9. D'Amore A., Giorgio M., Grassia L. Modeling the residual strength of carbon fiber reinforced composites subjected to cyclic loading // International Journal of Fatigue. 2015. Vol. 78. P. 31-37. doi: https://doi.org/10.1016/j.ijfatigue.2015.03.012

10. Fatigue delamination growth rates and thresholds of composite laminates under mixed mode loading / Zhang J., Peng L., Zhao L., Fei B. // International Journal of Fatigue. 2012. Vol. 40. P. 7-15. doi: https://doi.org/10.1016/j.ijfatigue.2012.01.008 
11. Influence of woven ply degradation on fatigue crack growth in thin notched composites under tensile loading / Bizeul M., Bouvet C., Barrau J. J., Cuenca R. // International Journal of Fatigue. 2010. Vol. 32, Issue 1. P. 60-65. doi: https://doi.org/ 10.1016/j.ijfatigue.2009.01.010

12. Bao H., McEvily A. J. The effect of an overload on the rate of fatigue crack propagation under plane stress conditions // Metallurgical and Materials Transactions A. 1995. Vol. 26, Issue 7. P. 1725-1733. doi: https://doi.org/10.1007/bf02670759

13. McEvily A. J., Yang Z. The nature of the two opening levels following an overload in fatigue crack growth // Metallurgical Transactions A. 1990. Vol. 21, Issue 10. P. 2717-2727. doi: https://doi.org/10.1007/bf02646067

14. Deceleration and acceleration of crack propagation after an overloading under negative baseline stress ratio / Makabe C., Purnowidodo A., Miyazaki T., McEvily Arthur J. // Journal Testing and Evaluation. 2005. Vol. 33, Issue 5. P. $181-187$.

15. Makabe C., Purnowidodo A., McEvily A. J. Effects of surface deformation and crack closure on fatigue crack propagation after overloading and under loading // International Journal of Fatigue. 2004. Vol. 26, Issue 12. P. 1341-1348. doi: https:// doi.org/10.1016/j.ijfatigue.2004.03.017

16. Transitional Behavior of Residual Fatigue Life After Applying Overload During Fatigue Crack Growth With Constant Stress Amplitude / Pumowidodo A., Miyazaki T., Makabe C., McEvily A. J. // Pressure Vessel and Piping Codes and Standards. 2004. P. 39-44. doi: https://doi.org/10.1115/pvp2004-2671

17. Barsom J. M., Rofle S. T. Stress Analysis for Members with Crack // Fracture and fatigue control in structure. 3rd ed. Philadelphia: ASTM, 1999.

18. The Effect of Stop Holes Technique on Crack Growth Behaviours Emanating From a Notch after Overloading / Purnowidodo A., Anam K., Wahyudi A., Arief S. // International Journal of Applied Engineering Research. 2014. Vol. 9, Issue 1. P. 125-136.

19. Topper T. H., Lam T. S. Derivation of crack closure and effective fatigue crack growth data from smooth specimen fatigue test // Report of Fatigue Branch of The Society of Materials Science Japan. 2003. Vol. 266. P. 1-12.

20. Ward-Close C. M., Blom A. F., Ritchie R. O. Mechanisms associated with transient fatigue crack growth under variable-amplitude loading: An experimental and numerical study // Engineering Fracture Mechanics. 1989. Vol. 32, Issue 4. P. 613-638. doi: https://doi.org/10.1016/0013-7944(89)90195-1

21. Sadananda K. Analysis of overload effects and related phenomena // International Journal of Fatigue. 1999. Vol. 21. P. 233246. doi: https://doi.org/10.1016/s0142-1123(99)00094-8

22. Crack Growth Behavior in Overloaded Specimens with Sharp Notch in Low Carbon Steel / Purnowidodo A., Fukuzato S., Saimoto A., Makabe C. // Journal of Testing and Evaluation. 2007. Vol. 35, Issue 5. P. 100097. doi: https://doi.org/10.1520/ jte100097 